\title{
Working
}

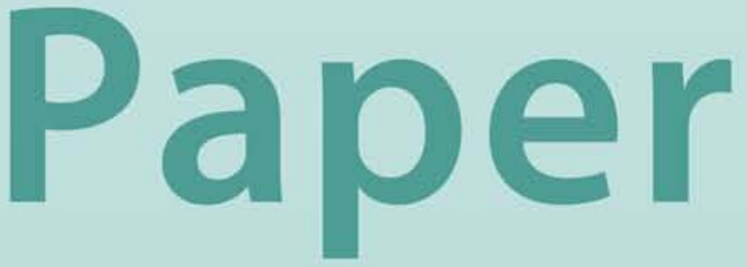


Determinants of Development Financing Flows from Brazil, Russia, India, and China to LowIncome Countries

Nkunde Mwase 


\title{
IMF Working Paper
}

Strategy, Policy, and Review Department

\section{Determinants of Development Financing Flows from Brazil, Russia, India, and China to Low Income Countries}

\author{
Prepared by Nkunde Mwase ${ }^{1}$
}

Authorized for distribution by Catherine Pattillo

November 2011

\section{This Working Paper should not be reported as representing the views of the IMF.} The views expressed in this Working Paper are those of the author(s) and do not necessarily represent those of the IMF or IMF policy. Working Papers describe research in progress by the author(s) and are published to elicit comments and to further debate.

\begin{abstract}
BRICs development financing flows have increased significantly and are expected to become more prominent in the post-crisis era. We investigate the potential implications on the countryallocation of loan commitments and the degree of concessionality using a panel vector autoregression model and single equation dynamic panel estimation.We find that BRICs lend more to LICs with weaker institutions. Land-locked, resource-scarce LICs receive significantly less financing than other resource-rich LICs. The degree of concessionality is negatively correlated with the amount of loans and positively correlated with better institutional indicators suggesting that the higher the risks, the higher the required returns that BRICs expect.
\end{abstract}

JEL Classification Numbers:C3, F3, F5, O5

Keywords: Aid, BRICs, Low-Income Countries, Panel VAR, Panel OLS, Concessionality

Author’s E-Mail Address:nmwase@imf.org

\footnotetext{
${ }^{1}$ I would like to thank Yongzheng Yang and Catherine Pattillo for inspiring and extensively reviewing this paper. In addition, grateful to Issouf Samake, Montie Mlachila, and Patrick Imam for their useful comments and to Ke Wang and Sibabrata Das for excellent research assistance.
} 




A. Stylized Facts on BRIC Financing ..............................................................

II. Determinants of Financing to LICs .......................................................................

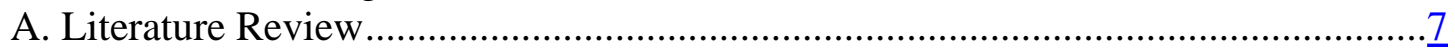

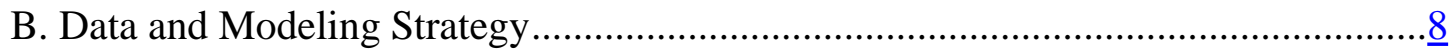

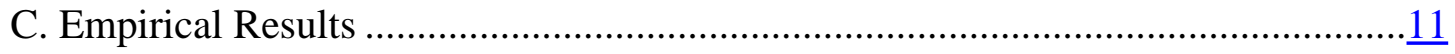

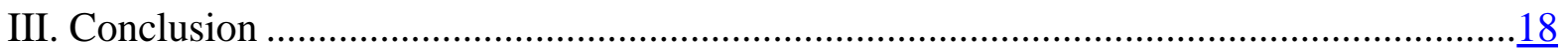

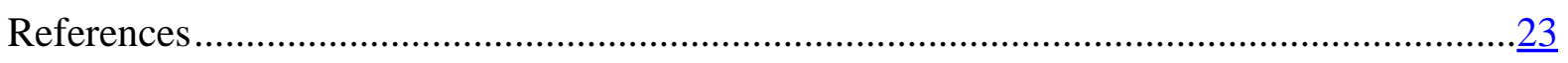

\section{Tables}

1. Results: The Determinants of the Amount of BRIC Financing .......................................16

2. Forecast Error Variance Decomposition of Loan Model................................................17

3. Forecast Error Variance Decomposition of Concessionality Model .................................17

\section{Figures}

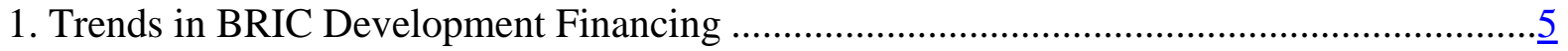

2. Global Concessional Development Assistance to LICs.....................................................

3. LICs: Top Ten Recipients of Development Assistance.................................................... 6

4. LICs: BRIC Financing and OECD Aid, by Resource and Region ..................................

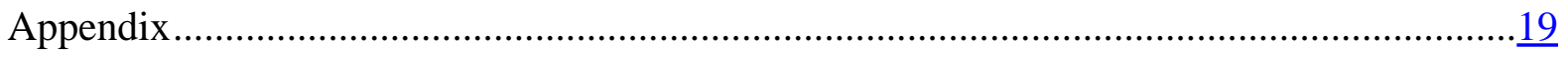

\section{Appendix Tables}

A.1 Country List .....................................................................................................

A.2 List of Variables in Dynamic Panel Analysis ...........................................................20

A.3 Variable Definitions in the Dynamic Panel Model ......................................................20

A.4 Panel Unit Root Test .............................................................................................

A.5 Model Stability Test...............................................................................................

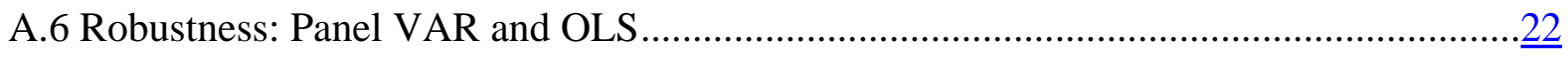




\section{INTRODUCTION}

Development financing flows from BRICs-Brazil, Russia, India and China-to low income countries (LICs) have increased in recent years, driven mostly by China, and are expected to become even more prominent in the post-crisis era. ${ }^{2}$ In contrast with many industrial countries which are facing large fiscal consolidation and consequent challenges to meet their aid commitments, BRICs are in a strong position to continue increasing their development financing. BRICs have brought new dynamics to the international aid architecture.

This paper attempts to answer two questions: what are the determinants of the amount of BRIC loan financing to LICs and the degree of concessionality of the financing. Since BRIC loan financing is generally less concessional than ODA and more concentrated in country distribution, this has raised concerns about the implications for debt sustainability. ${ }^{3}$ This paper contributes to the discussion by investigating whether BRICs allocate financing with sensitivity to income levels and the quality of countries' policy and institutional environment. In addition, we investigate whether financing is also sensitive to country size, trade ties, resource wealth, debt burden, and colonial/language linkages.

To address these questions, we employed a panel vector autoregression (VAR) model and single equation dynamic panel estimation. Like standard dynamic panel estimation, a panel VAR enables us to assess the relative importance of determinants of loans and concessionality. Further, it allows estimation to control for endogeneity and investigate causality among system variables.

The contribution of the paper to the literature is threefold: To the best of our knowledge, this is the first attempt to assess the determinants of BRICs loans to LICs. Second, the paper contributes to the literature on the determinants of aid in LICs which has mostly focused on OECD-DAC aid flows. Finally, the paper also examines the factors driving the degree of concessionality of development financing; this is important given concerns about the debt implications of BRIC financing.

The main findings are that BRIC loan financing and the degree of concessionality may be driven by commercial factors. Specifically:

- $\quad$ LICs with higher income and lower Country Policy and Institution (CPIA) scores tend to receive larger amounts of loan commitments. This suggests that more financing is provided to economies with governance issues. Landlocked resource-scarce countries are more likely to receive less financing than resource-rich countries suggesting that lending decisions may be driven by commercial factors.

\footnotetext{
${ }^{2}$ In this paper, "low-income countries" refers to all countries shown on the IMF's list of countries eligible for the Poverty Reduction and Growth Facility at end-December 2008.

${ }^{3}$ This, however, abstracts from the fact that other types of financing may be substantial (e.g., China provides non-reimbursable aid (i.e., grants) and interest-free loans in addition to preferential loans, but no annual data is available).
} 
- $\quad$ The degree of concessionality is negatively correlated with the amount of financing suggesting that BRIC financing could be based in part on a commercial calculationthe higher the risks, the higher the required returns. Consistent with this interpretation, countries with better institutional indicators also received greater concessionality. There is also some evidence that countries that export more to BRICs tend to get less concessional financing terms. While this may seem puzzling, these results could reflect BRICs offering better conditions in order to access new markets to satisfy their growing import needs. Not surprisingly, countries under a Fund-supported program tend to have higher concessionality of BRIC financing, albeit with lower loan amounts.

Since BRIC loan financing is generally less concessional than traditional ODA it is important to ensure that the financing is allocated to effective projects and financed in ways that do not jeopardize debt sustainability. The empirical finding that countries that have more BRIC loan financing are likely to receive lower concessionality suggests that LICs need to carefully assess the financing provided to ensure that the risks are fully taken into account.

The rest of the paper is organized as follows. Section II provides stylized facts of BRIC financing. Section III examines the empirical determinants of the BRIC loan financing and degree of concessionality and Section IV concludes.

\section{A. Stylized Facts on BRIC Financing}

BRIC development financing has surged in recent years, but remains significantly smaller than financial support provided by OECD donors. World Bank data suggest, including nonconcessional flows, total BRIC loan commitments amounted to about US\$26 billion in 20002008 compared to about US $\$ 296$ billion from the OECD during the same period (Figure 1). ${ }^{4}$ Estimates suggest that, in 2007, total BRIC concessional financing (grants and concessional loans) was about 3 percent of total concessional financing provided to LICs - nearly US $\$ 4$ billion compared to about US\$90 billion from traditional donors (Figure 2). ${ }^{5}$ These findings should be treated with caution given weaknesses in BRIC development financing data (See Appendix I).

\footnotetext{
${ }^{4}$ The sample set for both the OECD and BRIC data is limited to 49 LIC countries. The OECD data reflect total ODA commitments from all countries reporting to the OECD.

${ }^{5}$ Traditional donors are defined here as OECD-DAC members. Sources include Brautigam (2010) and OECD (2010).
} 
Figure 1. Trends in BRIC Development Financing, 2000-2008 1/
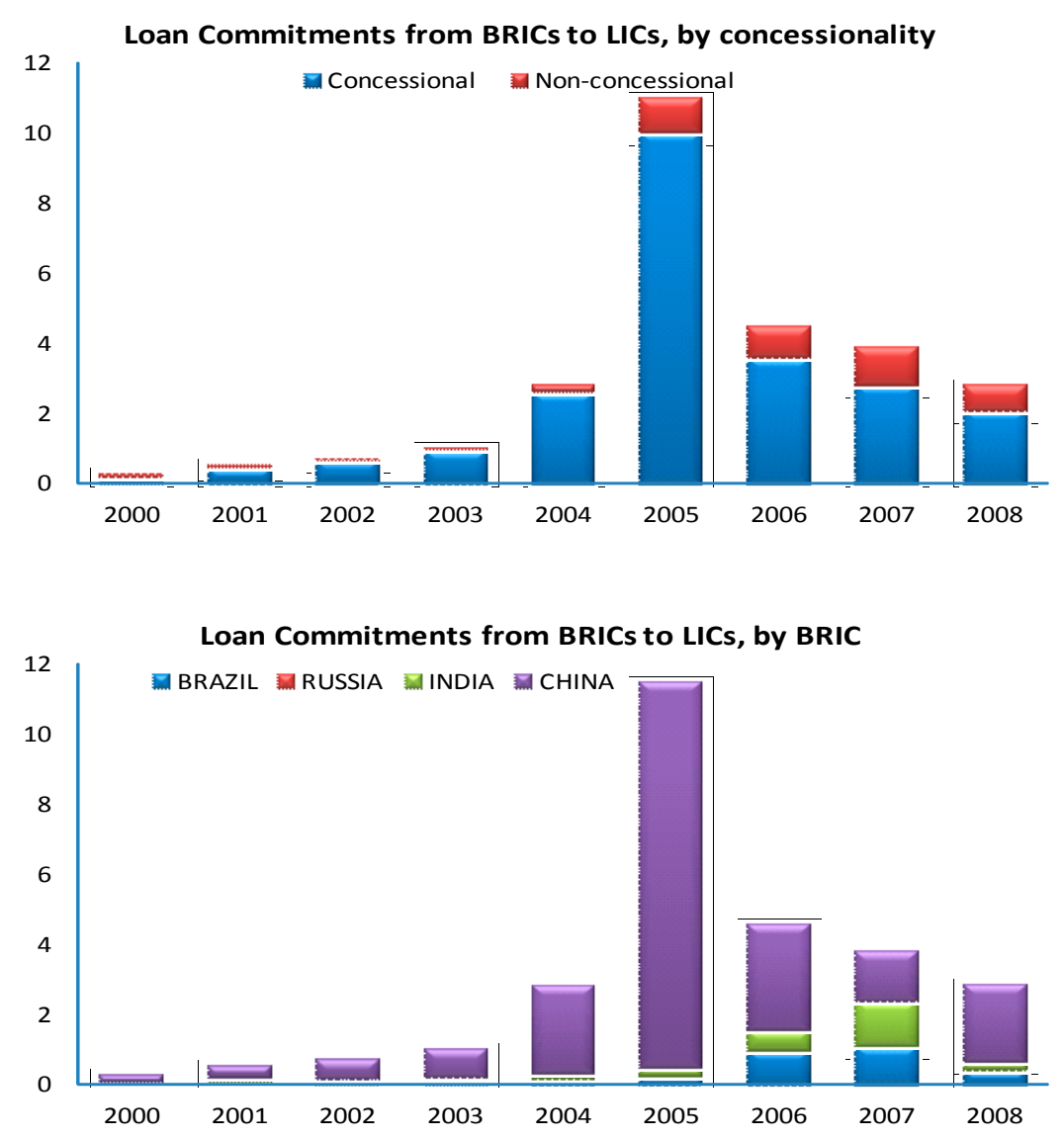

Source: World Bank debt database; IMF Grant Element Calculator, 2010.

${ }^{1 /}$ IMF minimum grant element is used to decompose into concessional and nonconcessional. The big spike in 2005 is driven by loan commitments to Angola.

The distribution of BRIC development financing among recipient countries differs somewhat from the traditional donors. Countries that receive the highest loan financing from BRICs (e.g., Bhutan, Angola and Tajikistan) generally differ from those that receive significant amounts of ODA from the OECD (Figure 3). Philosophical differences in development financing could be an important factor behind these differences (see Mwase and Yang, 2011). In contrast to traditional donors have stated that the objective of ODA is poverty reduction, all the BRICs, with the exception of Russia, have stated that their financing is driven by the principles of mutual benefits of cooperation and view themselves as development partners. 
Figure 2. Global Concessional Development Assistance to LICs, 2007 1/

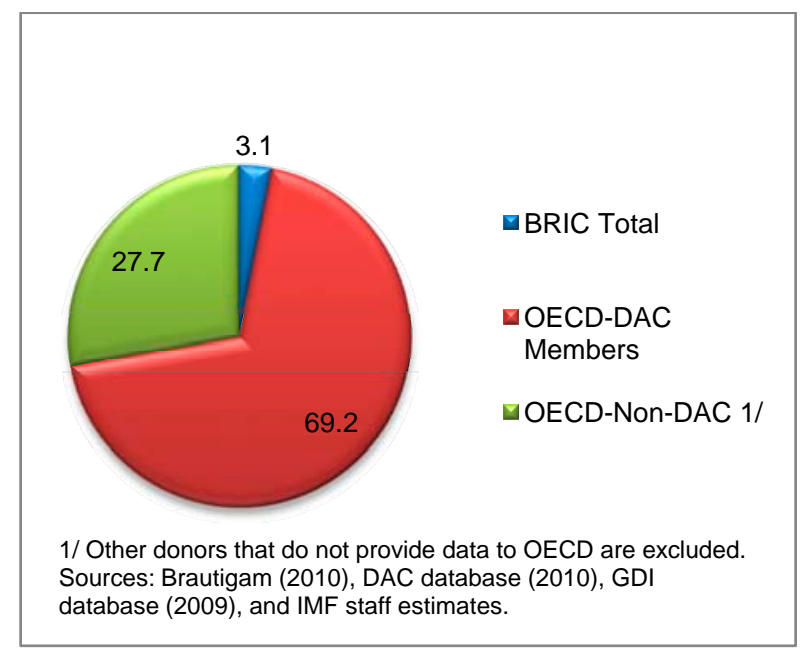

Figure 3. LICs: Top Ten Recipients of Development Assistance, 2000-2008 1/ (in US\$ millions)

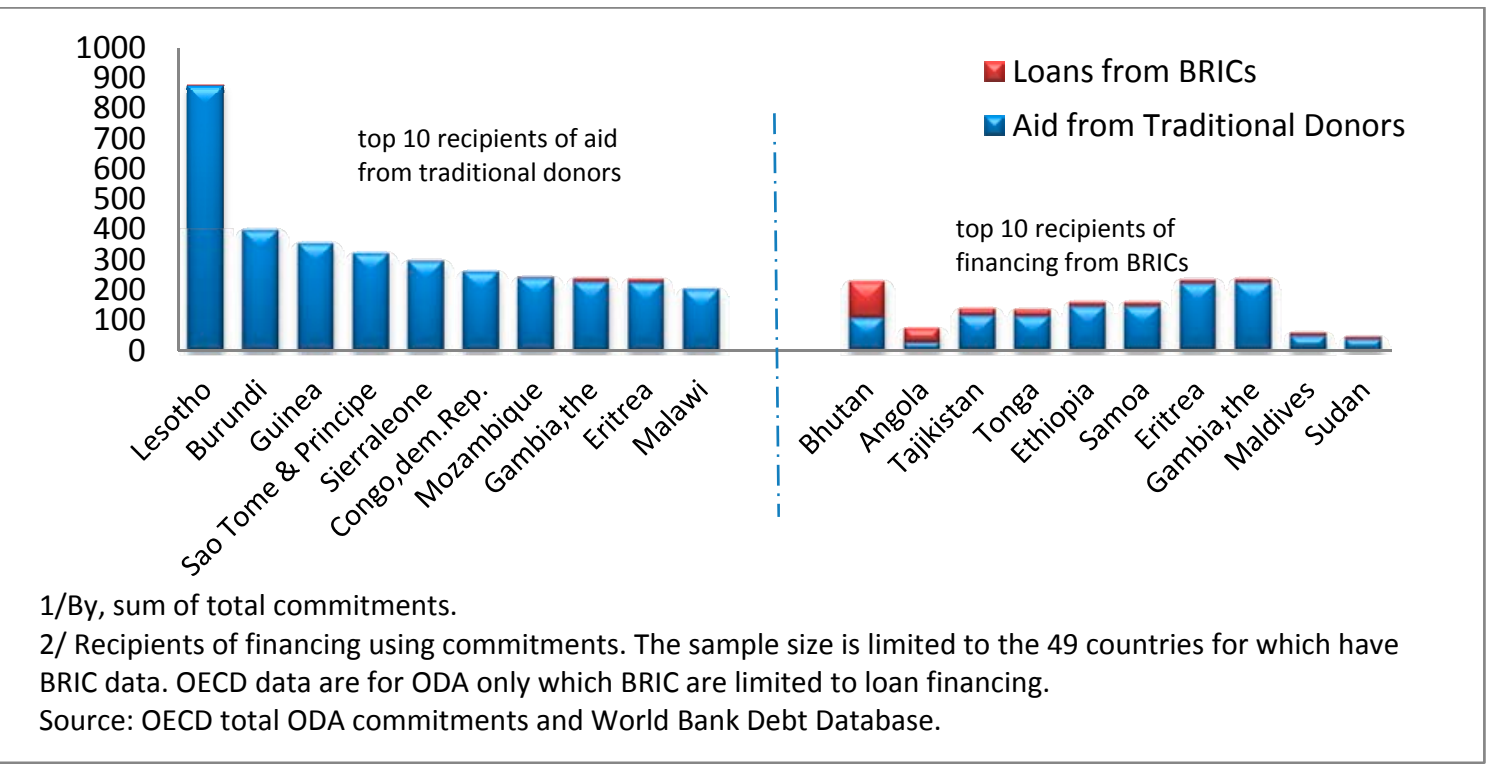

Source: OECD total ODA commitments and World Bank Debt Database.

Contrary to general perceptions, BRICs provide significant development financing (as a share of GDP) to resource-scarce LICs. Although in absolute amounts, BRICs tend to provide far more loan financing to resource-rich than resource-scarce LICs; this amounts to a bigger share of GDP in resource-scarce LICs averaging 1.7 percent of GDP between 2000 and 2008 (Figure 4). This pattern is similar to that of traditional donors. 
Regional and language ties play an important role. Flows from Brazil and Russia tend to be concentrated in Lusophone and CIS countries, respectively while those from India are concentrated in neighboring countries (Figure 4). China tends to provide a small amount of loan financing to a broad range of LICs. World Bank data show that Asian LICs received the highest amount of BRIC loan financing, as a share of GDP, closely followed by Africa. This is in line with empirical evidence that linguistic and colonial ties influence the allocation of OECD aid and that proximity to the OECD donors enhances the share of aid a country receives (Round and Odedokun, 2004). ${ }^{6}$

Figure 4. LICs: BRIC Development Financing and OECD Aid, by Resource and Region, 2000-2008

(in Percent of recipient GDP)

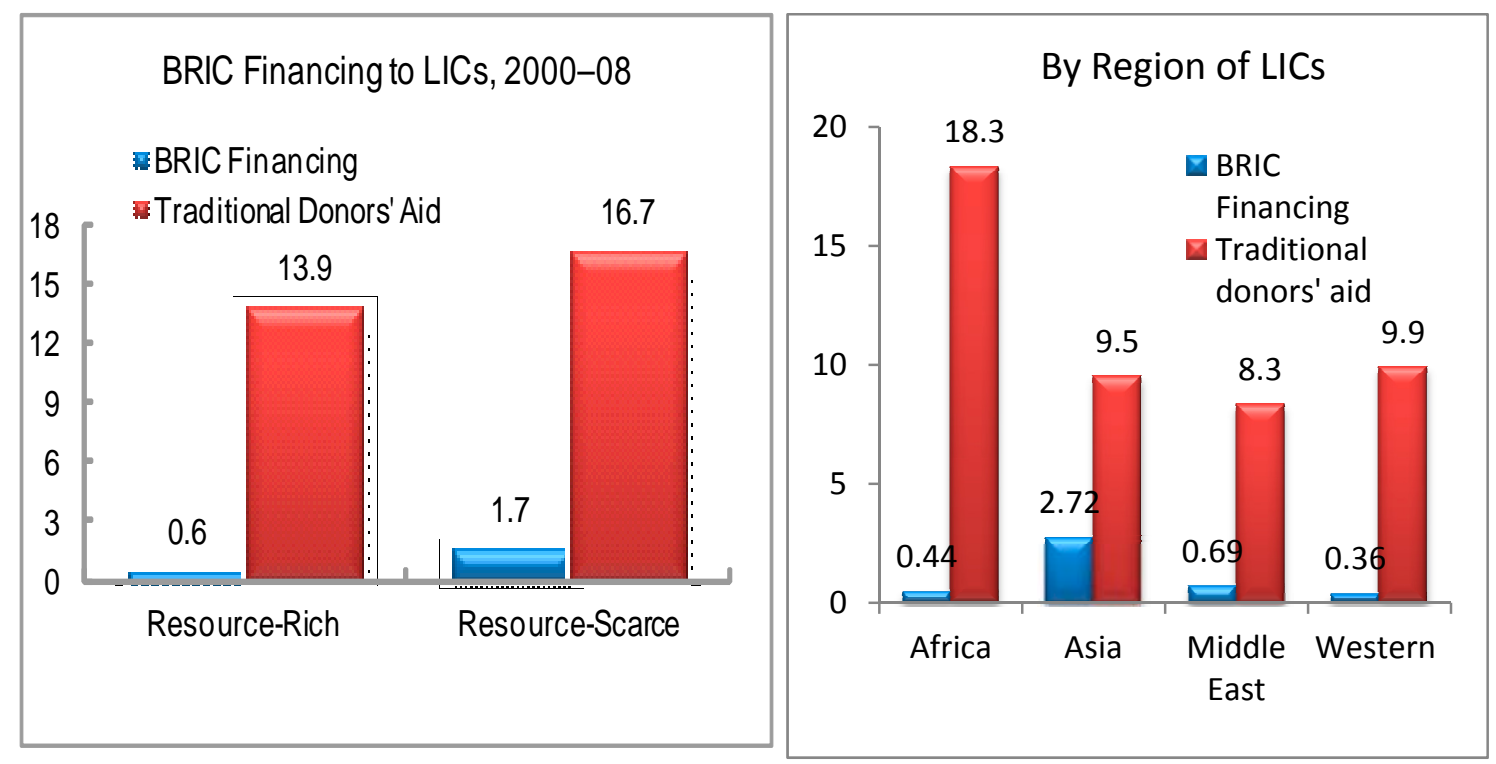

Source: World Bank debt database and OECD ODA commitment data, and IMF staff estimates.

\section{DETERMinANTS OF FINANCING TO LICs}

\section{A. Literature Review}

The literature has focused on determinants of OECD aid allocation across recipients: ${ }^{7}$ Early studies of aid allocation tended to apply some version of the Maizels and Nissanke (1984) and McKinlay and Little (1979) dichotomy, but more recent studies have augmented this to

\footnotetext{
${ }^{6}$ The World Bank data show that in absolute terms (in US\$), the largest recipients of BRIC financing is Africa and is closely followed by Asia. Data on financing to European LICs is unavailable.

${ }^{7}$ A few studies on non-OECD countries, mostly Arab donors, have also been undertaken.
} 
include a third set of variables. Three groups of independent variables are thus used in the estimations:

- LIC's needs. Providing more financing to countries with higher need for assistancethis can relate to "shortfalls either in its domestic resources or in its foreign exchange availability...or both" (Maizels and Nissanke, 1984). Variables used have included income (in levels and per capita) ${ }^{8}$ and infant mortality.

- LIC's institutional framework. Providing more financing to countries with sound institutions could help improve the effectiveness of development assistance and provide an incentive for countries to strengthen governance. Burnside and Dollar (2000, 2004) argue that countries with good policies should be able to absorb large volumes of aid and use this more effectively. A broad range of variables have been considered including governance indicators (Kaufmann et al., 2009), CPIA index, and political and civil rights indices (Freedom House).

- Donor interest. Development assistance could be designed to promote donor’s "political/security, investment and trade interests" (Maizels and Nissanke, 1984). Variables used to proxy donor interest have included geography (region or distance from capitals), trade, FDI stock, and arms imports.

The literature on the concessionality of development financing is scarce and limited to a few papers examining the impact of loan concessionality on recipient countries' borrowing patterns and optimal concessionality for LICs. ${ }^{9}$

The literature has tended to find that, at least until the early 1990s, variables that proxied donor interest were more important than those representing growth, poverty reduction or other economic objectives in aid allocations (Claessens et al., 2007; Kosack, 2003; Radelet, 2006; and Neumayer, 2003).

\section{B. Data and Modeling Strategy}

In view of the low frequency of the data and the limited number of observations for each country, we consider a panel framework. Pooling is advantageous given the short-time dimension (annual data from 2000-2008) and wide cross-section (49 LICs). Information on the country list is presented in Appendix (Table A1).

\footnotetext{
${ }^{8}$ However, to the extent that granting agencies concentrate on economic performance, project quality and development plan requirements, higher income countries usually score higher marks on all these counts. Also, higher income countries could have higher needs and income could also capture other factors such as macroeconomic stability. Though income could also proxy factors besides needs, it remains the single most comprehensive proxy for wellbeing and therefore a country's need (e.g., Easterly (1999) and Neumayer (2003).

${ }^{9}$ See Odedokun (2004), Cordella and Ulku (2004), and Koeda (2004).
} 
The panel VAR model fits our attempt to understand BRIC development financing dynamics. A key advantage of using VARs over standard cross-sectional regressions is their ability to look at the dynamics effects of shocks to the exogenous variables on the dependent variables unlike cross-sectional regressions which can only estimate a one-period effect.

We specify the following first-order panel VAR model. ${ }^{10}$

$Y_{i t}=A_{0}+A_{1} Y_{i t-1}+A_{2} X_{i t}+\mu_{i}+\varepsilon_{i t}$

where

$\mathrm{Y}_{\mathrm{it}}$ is a vector of endogenous variables, $\mathrm{X}_{\mathrm{it}}$ is a vector of explanatory variables and $\boldsymbol{\varepsilon}_{\boldsymbol{i t}}$ is a vector of errors. The vector of endogenous variables comprises BRIC development loans as a share of GDP (loan) and the degree of concessionality of the loan (Conc). We use commitment data as this is a decision variable over which donors exercise full control. ${ }^{11}$

The panel VAR is given by

$$
Y_{i t}=\left\lfloor\operatorname{loan}_{i t}, \text { Conc }_{i t}\right\rfloor^{\prime}
$$

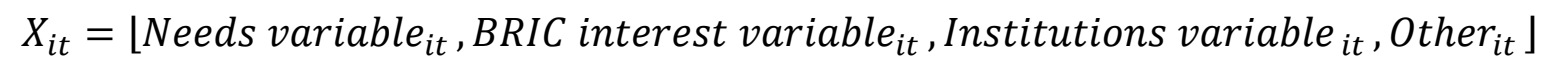

$$
\begin{gathered}
\boldsymbol{\varepsilon}_{i t} \sim \boldsymbol{n}\left(\mathbf{0}, \boldsymbol{\sigma}_{\epsilon_{i t}}^{2}\right) \\
\in\left(\varepsilon_{i t}, \varepsilon_{j s}\right)=\mathbf{0} \quad \boldsymbol{j} \neq \boldsymbol{i} t \neq s \\
\in\left(\boldsymbol{\mu}_{i}, \varepsilon_{j t}\right)=\mathbf{0} \quad \forall_{i, j, t} \\
\in\left(x_{i t}, \varepsilon_{j s}\right)=\mathbf{0} \quad \forall_{i, j, t, s}
\end{gathered}
$$

A number of exogenous variables are considered to capture the impact of needs, BRIC interest, institutions and to control for other factors (see Tables A2-A3 for a summary and discussion of sources and definition). Specifically: ${ }^{12}$

- Income: We include income per capita relative to the average LIC income per capita in that particular year as a proxy for needs. This addresses the potential endogeneity of income.

- $\quad$ BRIC commercial interests: We examine the share of exports to BRICs as a share of GDP in the baseline model. In alternative model specifications, we consider the impact

\footnotetext{
${ }^{10}$ This expression is a typical panel VAR-X model where $\mathrm{X}$ is assumed to be strongly exogenous to the system (see Bierens, 2004). While all variables in the model are assumed to be endogenous in a simple VAR model, a VARX model allows some of the variables to be exogenous.

${ }^{11}$ White and McGillivray (1995) note that disbursements might be affected by other factors over which donors' have no control. Since this paper is not analyzing the economic impact of the financing and is instead focusing on factors affecting the decision to allocate financing to a country, commitment data is more suitable than disbursement data.

${ }^{12}$ We include a discrete variable to control for whether or not a country has received loan commitments since some countries do not have loan commitments on a continuous basis.
} 
of imports from BRICs as a share of GDP. The empirical literature has examined the role of trade interests of the donor (using either the proportion of recipient country exports, imports or trade with the donor). The aid literature has noted that development financing could be used to promote the donor's export markets (i.e., more financing is provided to countries that import more from the donor) or it may be used to promote export ties with those countries which currently constitute lesser export markets (i.e., providing more financing to countries that have lower import volumes) (Gounder, 1994; McGillivray and Oczkowski, 1992). ${ }^{13}$

- $\quad$ BRIC strategic political interest: We proxy this using geography and apply regional dummies. The sample included countries from four regions: Africa, Asia and Pacific Islands, Middle East and Central Asia, and Latin America and the Caribbean (LAC). ${ }^{14}$ The aid literature has noted a tendency of donors to give much of their aid to neighboring recipients (Neumayer, 2003; Round and Odedokun, 2004). We also consider the impact of colonial and language ties using dummies. ${ }^{15}$

- $\quad$ Endowment: This is the first paper in the aid literature that we are aware of that examines the impact of mining natural resources (interacted with location). Drawing on Collier and O'Connell, 2007 we also consider the role of location, proxied by three categories: coastal resource-scarce; landlocked, resource-scarce, and resource-rich (whether coastal or landlocked). ${ }^{16}$

- Institutions: We consider the impact of CPIA, governance indicators as well as other institutional indicators that have not as yet been considered in the aid literature (e.g., the recently-constructed planning and transparency indices). This would enable us to examine whether more financing is provided to economies with weaker institutions. Manning (2006) and others have argued that the country allocation of BRIC financing could undermine efforts to improve governance in BRICs.

\footnotetext{
${ }^{13}$ The aid literature has also considered the role of FDI in influencing donor interests but notes the paucity of FDI data (Gounder, 1994; Hopkins, 2000, and Maizels and Nissanke, 1984). Due to lack of comprehensive reliable data on FDI for BRICs we did not consider the impact of FDI flows. The investment interest of a donor would be promoting growth, or alleviating economic difficulties in a recipient country in which the donor has substantial investments. Aid to such countries would, in effect, constitute an external subsidy to ensure continuing profitability of the foreign investments of enterprises of the donor country. Using the limited data available, we did not find evidence of a strong correlation between BRIC FDI and development financing.

${ }^{14}$ No data is available on European LICs.

${ }^{15}$ We examined whether there was a difference in BRIC financing flows to former British, French, Portuguese and Spanish colonies. We also considered the impact of the recipient country sharing language ties (e.g., Portuguese as well as languages spoken in India and China).

${ }^{16}$ Since countries with coastlines can be effectively landlocked, following Sachs (2003) we define countries by whether or not they have a port.
} 
- Government consumption: We consider the impact of government consumption, as a share of GDP (lagged by one period to address potential endogeneity). This variable could reflect LIC government's demand for financing.

- $\quad$ Fund programs: LICs with high risk of debt distress and with a Fund-supported program would be expected to receive either lower amount of financing and/or a higher degree of concessionality given that the conditionality in these programs is designed to contain borrowing. We include a dummy variable to capture the impact of programs.

- $\quad$ Population: We control for the impact of population on development financing. Although findings have been mixed, some past studies have pointed to systematic positive "small country" biases (i.e., more given to countries with smaller population size) in aid allocation. ${ }^{17}$

- Aid coordination: We proxy this using ODA commitments as a share of GDP. Some studies control for the tendency for OECD-DAC donors to coordinate and complement ("band wagon" effect) their aid flows (Claessens et al., 2007; McGillivray and Oczkowski, 1992).

\section{Empirical Results}

Unit root tests results indicate that the variables follow are stationary (see Table A4). The model variables are stable and no root lies outside the unit circle (Table A5). Lag length criteria (AIC, SC) and the LR test statistic suggest an autoregressive structure of order 1.

\section{Determinants of loan commitments}

Overall we find that income and the size of government have a positive and significant impact on the loan commitments, while the CPIA has a negative impact (Table 2). More specifically:

- A 100 percent increase in a countries' income per capita relative to the mean income per capita is associated with a 0.1 percent to 0.2 percent increase in BRIC financing. This finding is robust to alternative model specifications (Table 2, models 1-4). This could imply that LICs with relative higher income per capita receive significantly more financing suggesting that BRIC financing is not necessarily need-based.

However its low economic impact suggests that it is not very important determinant of BRIC financing. ${ }^{18}$ In contrast, recent empirical studies examining traditional donors find that poorer countries receive more aid and note that the responsiveness of aid to recipient country income has increased overtime (Claessens et al., 2007).

\footnotetext{
${ }^{17}$ Radelet (2006) and Kosack (2003) argues, donors generally want to influence as many countries as possible which tends to lead to a disproportionate amount of aid going to small countries while Kosack (2003) notes that donors may prefer to allocate their limited aid where it will have the greatest impact per person.

${ }^{18}$ This is confirmed later in the variance decompositions.
} 
- A 100 percent increase in a countries’ CPIA index implies a 0.3 decrease in BRIC financing (Table 2, models 1-2). The other institutional indicators (planning, and transparency) are negatively related with BRIC financing but insignificant (models 34). ${ }^{19}$ The CPIA score result underscores concerns that BRIC financing could undermine efforts to improve governance in LICs.

- A 100 percent increase in government consumption as a share of GDP, is associated with a 1.2 percent to 1.6 percent increase in BRIC financing. ${ }^{20}$ This implies that LICs with higher government size tend to receive more BRIC financing and is broadly in line with the literature on traditional donors' aid allocation (e.g., Ali and Isse, 2006).

Control variables to take into account the impact of geography, endowment and IMF programs also matter. The endowment variable provides some weak evidence that landlocked, resource-scarce LICs receive significantly less financing than resource-rich countries. ${ }^{21}$ The geography variable indicates that Asian LICs tend to receive significantly more aid while LAC LICs tend to receive significantly less. ${ }^{22}$ Since most of the BRIC financing is from the China and India, these results are broadly in line with the literature on the impact of proximity on aid allocation. ${ }^{23}$

\section{Determinants of the degree of concessionality of loan commitments}

The concessionality of BRIC loan commitment may also be influenced by commercial factors. Overall, we find that LIC exports to BRICs, government size, and BRIC loan commitments have a negative and significant impact on concessionality, while the institutional variables (CPIA, transparency and planning) have a positive and significant effect (Table 2).

- A one percent increase in loan commitments is associated with a 10 percent decrease in the degree of concessionality, implying that LICs that have higher BRIC loan commitments tend to receive less concessional terms. This suggests that BRICs financing could be based in part on a commercial calculation — the higher the risks (as reflected by exposure to a country), the higher the required returns. ${ }^{24}$

\footnotetext{
${ }^{19}$ In addition, the Kaufmann governance effectiveness indicator is not significant. Since this variable is not significant in both equations, and for brevity, we do not show the findings from this model specification.

${ }^{20}$ These findings are robust to alternative specifications without any institutional indicators (i.e., CPIA, planning, transparency). Correlation analysis suggests that the institutional indicators, government size and relative income are not strongly correlated. For example, the correlation between CPIA and relative income was less than 0.31.

${ }^{21}$ A number of observations that were large outliers were dropped in the empirical analysis. An alternative model specification using the resource-rich LICs dummy variable (not reported for brevity) is insignificant.

${ }^{22}$ For brevity, the alternative specifications using LAC, Middle Eastern and African LICs are not presented.

${ }^{23}$ We did not obtain significant results for the impact of colonial ties or language ties perhaps reflecting the dominance of Chinese flows which has a more diversified geographical coverage of countries.

${ }^{24}$ The overall debt position of a country did not have a significant impact. This finding is broadly in line with findings from aid literature (e.g., Claessens, 2007) that concerns among OECD donors about countries’ debt burdens have declined over time. The aid literature generally finds that while in the late 1980s and early 1990s, high debt was a reason behind lower levels of aid (and the coefficient was negative and significant), since then it
}

(continued...) 
- $\quad$ A one percent increase in the CPIA index is associated with a 0.3 percent increase in the concessionality of BRIC financing (models 1-2). A one percent increase in the planning index implies a 0.13 percent increase in financing (model 3); a similar result is obtained for transparency index (model 4). This suggests that LICs with better institutional indicators received greater concessionality. This could reflect BRICs taking into account the riskiness of their lending.

- $\quad$ A one percent increase in government consumption as a share of GDP is associated with a 0.8 percent to 1.3 percent decrease in the degree of concessionality implying that LICs with higher government size receive less concessional financing. This could reflect commercial calculations (see findings on loan amount) or may reflect LICs demanding more financing and willing to incur a higher cost.

- A one percent increase in exports, as a share of GDP to BRICs, is associated with a 2.3 percent to 2.7 percent decrease in the degree of concessionality implying that LICs that export a higher share of their exports to BRICs receive less concessional financing. While this may seem puzzling, this result could reflect BRICs seeking to access new markets to satisfy their growing import needs (and so offering better terms to these new markets where trade volumes are low). ${ }^{25}$

Control variables to take into account the impact of population, IMF programs, geography, and complementarity with traditional donors also matter.

- $\quad$ LICs with a Fund program tend to receive significantly more concessional financing. This could reflect the limited debt servicing capacity of these recipients or limits on concessionality in Fund programs. ${ }^{26}$

- $\quad$ LAC LICs tend to receive significantly more concessional financing while African LICs significantly less. This is interesting since LAC LICs receive significantly less financing from BRICs.

- A one percent increase in population size is associated with a 0.03 percent decrease in BRIC financing suggesting that there is a "small country" bias. However, this finding is sensitive to alternative model specifications.

- $\quad$ A one percent increase in ODA flows, as a share of GDP, that a LIC receives is associated with a 0.5 percent increase in the degree of concessionality. This implies that BRICs tend to provide more concessional terms to LICs that receive more ODA. Overall, these findings suggest that there could be competition across the various

aid flows are no longer significantly affected by the level of debt of the countries. This could reflect the impact of bilateral and multilateral debt reductions over this period.

${ }^{25}$ The impact of trade was also considered; but was insignificant.

${ }^{26}$ We did not decompose the sample into concessional and nonconcessional financing mainly due to limited dataset. In addition, the definition of Fund concessionality tends to vary across countries and overtime reflecting the risk profile of a country (primarily debt sustainability concerns). 
donor partners with more favorable terms offered to LICs that receive financing from both BRICs and other donors. ${ }^{27}$

Since countries that obtain more loan financing tend to receive less concessional terms, this suggests that LICs need to carefully assess the financing provided (coupled with the concessionality) to ensure that the debt implications are fully taken into account.

\section{Robustness}

We will examine the sensitivity of the results to alternative methodologies commonly used in the aid literature since the panel VAR has been criticized by some for imposing the restriction that the underlying structure is the same across country.

We applied a panel ordinary least squares (OLS) model (Table A6). ${ }^{28}$ The findings are broadly in line with the panel VAR - most of the variables that are significant in the panel VAR are also significant in the panel OLS. The panel general method of moments (GMM) estimator was also considered but was problematic because the available instruments are weak and the time period is rather short.

However, these alternative methodologies have a number of weaknesses. The fixed effects and instrumental variable (GMM-based) estimators overcome the restriction on the parameters but have significant drawbacks. Since the fixed effects are correlated with the regressors due to lags of the dependent variables, the mean-differencing procedure commonly used to eliminate fixed effects would create biased coefficients. When the instruments used in the GMM estimation are only weakly correlated with the instrumented variables, this can in turn give rise to biased coefficient estimates and hypothesis tests with large size distortions (Stock and Yogo, 2002).

\section{Variance Decompositions}

We examine the relative importance of the shocks to the economic variables in the model explaining changes in the BRIC financing. They provide out of sample causality tests, by partitioning the variance of the forecast error of a variable into proportions attributable to shocks in each variable including its own. To identify the structural parameters for the VAR, a set of restrictions are specified. Following Sims (1980), the reduced-form errors are orthoganalized through Cholesky decomposition.

We find that government size and whether a country has a Fund program are the two most important explanatory variables, accounting for 13 percent and 14 percent, respectively, of the

\footnotetext{
${ }^{27}$ A counterargument could be that LICs that receive more financing from traditional donors have greater need. However, as indicated in the literature review, the aid literature has not provided strong support for "needs" argument.

${ }^{28}$ For the panel OLS, we apply a general OLS specification since several of the variables do not vary within cross-sections and are not identified in a fixed effects specification. Due to data limitations, we could not decompose the sample into two periods to capture recent changes in India and China's engagement with LICs (in particular Africa).
} 
variation in BRIC loan commitments. The CPIA score was also an important driver accounting for 8 percent of the variation in BRIC loan commitments. Though the total contribution of these variables appears to be large and lasting, other factors may be more important in explaining the variation in BRIC financing given the importance of loan commitments in explaining its own innovations. In the period right after a shock, loan commitments explains about 53 percent of its own shocks and has strong persistence (Table 3).

The amount of loan commitments and whether a country has a Fund program are the two most important variables, aside from own innovations, driving variation in the degree of concessionality. These two variables account for a total of 27 percent of the variation (Table 4). Own innovations (i.e., variation of the degree of concessionality in response to its own shocks) explains the predominance of its own shocks; in the period right after a shock, it explains about 65 percent of its own shocks and has a large and lasting effect. In contrast, CPIA, size of government and ODA flows have a small contribution totaling about 8 percent, suggesting that they have a small economic impact. 
Table 1. Results: The Determinants of the Amount of BRIC Financing, Panel VAR $^{1 /}$

\begin{tabular}{|c|c|c|c|c|c|c|c|c|}
\hline \multirow[b]{3}{*}{ Variables } & \multirow{2}{*}{\multicolumn{2}{|c|}{$\frac{\text { Baseline model }}{\text { (Model 1) }}$}} & \multicolumn{6}{|c|}{ Alternative specification } \\
\hline & & & (Mod & & (Mod & el3) & (Moc & el 4) \\
\hline & Loan & $\begin{array}{l}\text { Concession- } \\
\text { ality }\end{array}$ & Loan & $\begin{array}{l}\text { Concession- } \\
\text { ality }\end{array}$ & Loan & $\begin{array}{c}\text { Concession- } \\
\text { ality }\end{array}$ & Loan & $\begin{array}{l}\text { Concession- } \\
\text { ality }\end{array}$ \\
\hline Loan (1 year lag) & $\begin{array}{l}0.089 \\
(0.052)^{* *}\end{array}$ & $\begin{array}{l}-10.150 \\
(3.354)^{* * *}\end{array}$ & $\begin{array}{l}0.092 \\
(0.053)^{* *}\end{array}$ & $\begin{array}{l}-9.825 \\
(3.364)^{* *}\end{array}$ & $\begin{array}{l}0.088 \\
(0.053)^{*}\end{array}$ & $\begin{array}{l}-9.565 \\
(3.383)^{* * *}\end{array}$ & $\begin{array}{c}0.089 \\
(0.053)^{*}\end{array}$ & $\begin{array}{l}-9.564 \\
(3.390)^{* * *}\end{array}$ \\
\hline Concessionality (1 year lag) & $\begin{array}{c}0.000 \\
(0.000)\end{array}$ & $\begin{array}{l}0.076 \\
(0.027)^{* * *}\end{array}$ & $\begin{array}{c}0.000 \\
(0.000)\end{array}$ & $\begin{array}{l}0.075 \\
(0.027)^{* * *}\end{array}$ & $\begin{array}{l}-0.0005 \\
(0.000)\end{array}$ & $\begin{array}{l}0.083 \\
(0.027)^{* * *}\end{array}$ & $\begin{array}{l}-0.0005 \\
(0.000)\end{array}$ & $\begin{array}{l}0.0842 \\
(0.027)^{* * *}\end{array}$ \\
\hline GDP p.c ratio (1 year lag) & $\begin{array}{l}0.002 \\
(0.001)^{* *}\end{array}$ & $\begin{array}{l}-0.072 \\
(0.058)\end{array}$ & $\begin{array}{l}0.002 \\
(0.001)^{* *}\end{array}$ & $\begin{array}{l}-0.061 \\
(0.058)\end{array}$ & $\begin{array}{c}0.001 \\
(0.001)^{*}\end{array}$ & $\begin{array}{l}-0.014 \\
(0.061)\end{array}$ & $\begin{array}{c}0.001 \\
(0.001)^{*}\end{array}$ & $\begin{array}{l}-0.010 \\
(0.062)\end{array}$ \\
\hline ODA & $\begin{array}{c}0.002 \\
(0.000)\end{array}$ & $\begin{array}{l}0.501 \\
(0.019)^{* *}\end{array}$ & $\begin{array}{c}0.003 \\
(0.005)\end{array}$ & $\begin{array}{l}0.655 \\
(0.304)^{* *}\end{array}$ & $\begin{array}{c}0.003 \\
(0.005)\end{array}$ & $\begin{array}{l}0.465 \\
(0.310)^{*}\end{array}$ & $\begin{array}{c}0.003 \\
(0.005)\end{array}$ & $\begin{array}{c}0.482 \\
(0.312)^{*}\end{array}$ \\
\hline IMF Program (incl. PSI) & $\begin{array}{l}-0.001 \\
(0.002)\end{array}$ & $\begin{array}{l}0.225 \\
(0.108)^{* * *}\end{array}$ & $\begin{array}{l}-0.001 \\
(0.002)\end{array}$ & $\begin{array}{l}0.230 \\
(0.108)^{* *}\end{array}$ & $\begin{array}{l}-0.003 \\
(0.002)^{*}\end{array}$ & $\begin{array}{l}0.287 \\
(0.102)^{* * *}\end{array}$ & $\begin{array}{l}-0.003 \\
(0.002)^{*}\end{array}$ & $\begin{array}{l}0.291 \\
(0.102)^{* * *}\end{array}$ \\
\hline Asia & $\begin{array}{l}0.009 \\
(0.003)^{* * *}\end{array}$ & $\begin{array}{l}0.002 \\
(0.180)\end{array}$ & $\begin{array}{l}0.009 \\
(0.003)^{* * *}\end{array}$ & $\begin{array}{r}0.000 \\
(0.181)\end{array}$ & $\begin{array}{l}0.008 \\
(0.003)^{* * *}\end{array}$ & $\begin{array}{c}0.108 \\
(0.183)\end{array}$ & $\begin{array}{l}0.008 \\
(0.003)^{* * *}\end{array}$ & $\begin{array}{l}0.102 \\
(0.183)\end{array}$ \\
\hline Population & $\begin{array}{c}0.000 \\
(0.000)\end{array}$ & $\begin{array}{l}-0.034 \\
(0.019)^{* *}\end{array}$ & $\begin{array}{c}0.000 \\
(0.000)\end{array}$ & $\begin{array}{l}-0.022 \\
(0.018)\end{array}$ & $\begin{array}{c}0.000 \\
(0.000)\end{array}$ & $\begin{array}{l}-0.040 \\
(0.019)^{* *}\end{array}$ & $\begin{array}{c}0.000 \\
(0.000)\end{array}$ & $\begin{array}{l}-0.042 \\
(0.019)^{* *}\end{array}$ \\
\hline Resource-Scarce Port & $\begin{array}{l}-0.001 \\
(0.003)\end{array}$ & $\begin{array}{c}0.091 \\
(0.197)\end{array}$ & $\begin{array}{c}0.000 \\
(0.003)\end{array}$ & $\begin{array}{c}0.171 \\
(0.194)\end{array}$ & $\begin{array}{l}-0.001 \\
(0.003)\end{array}$ & $\begin{array}{c}0.041 \\
(0.203)\end{array}$ & $\begin{array}{l}-0.001 \\
(0.003)\end{array}$ & $\begin{array}{l}-0.003 \\
(0.210)\end{array}$ \\
\hline Resource-Scarce Landlocked & $\begin{array}{l}-0.005 \\
(0.003)^{*}\end{array}$ & $\begin{array}{c}0.079 \\
(0.208)\end{array}$ & $\begin{array}{l}-0.005 \\
(0.003)^{*}\end{array}$ & $\begin{array}{c}0.094 \\
(0.209)\end{array}$ & $\begin{array}{l}-0.006 \\
(0.003)^{* *}\end{array}$ & $\begin{array}{c}0.141 \\
(0.208)\end{array}$ & $\begin{array}{l}-0.006 \\
(0.003)^{*}\end{array}$ & $\begin{array}{c}0.105 \\
(0.208)\end{array}$ \\
\hline Size of Government (1 year lag) & $\begin{array}{c}0.016 \\
(0.009)^{*}\end{array}$ & $\begin{array}{l}-1.279 \\
(0.580)^{* *}\end{array}$ & $\begin{array}{l}0.015 \\
(0.009)^{* *}\end{array}$ & $\begin{array}{l}-1.449 \\
(0.572)^{* * *}\end{array}$ & $\begin{array}{l}0.012 \\
(0.009)^{*}\end{array}$ & $\begin{array}{l}-0.758 \\
(0.569)^{*}\end{array}$ & $\begin{array}{l}0.012 \\
(0.009)^{*}\end{array}$ & $\begin{array}{l}-0.767 \\
(0.569)^{*}\end{array}$ \\
\hline CPIA & $\begin{array}{l}-0.003 \\
(0.002)^{* *}\end{array}$ & $\begin{array}{l}0.277 \\
(0.096)^{* * *}\end{array}$ & $\begin{array}{l}-0.003 \\
(0.001)^{* *}\end{array}$ & $\begin{array}{l}0.301 \\
(0.096)^{* * *}\end{array}$ & & & & \\
\hline Planning Index & & & & & $\begin{array}{l}-0.001 \\
(0.001)\end{array}$ & $\begin{array}{l}0.131 \\
(0.053)^{* * *}\end{array}$ & & \\
\hline Transparency Index & & & & & & & $\begin{array}{l}-0.001 \\
(0.001)\end{array}$ & $\begin{array}{l}0.139 \\
(0.061)^{* * *}\end{array}$ \\
\hline Exports to BRICs (1 year lag) & $\begin{array}{l}-0.021 \\
(0.020)\end{array}$ & $\begin{array}{l}-2.339 \\
(1.280) * *\end{array}$ & & & $\begin{array}{l}-0.017 \\
(0.020)\end{array}$ & $\begin{array}{l}-2.511 \\
(1.278)^{* *}\end{array}$ & $\begin{array}{l}-0.016 \\
(0.020)\end{array}$ & $\begin{array}{l}-2.659 \\
(1.273)^{* *}\end{array}$ \\
\hline Imports from BRICs (1 year lag) & & & $\begin{array}{c}0.004 \\
(0.010)\end{array}$ & $\begin{array}{c}0.327 \\
(0.641)\end{array}$ & & & & \\
\hline Trend & $\begin{array}{l}0.001 \\
(0.000)^{* *}\end{array}$ & $\begin{array}{l}0.007 \\
(0.021)\end{array}$ & $\begin{array}{l}0.000 \\
(0.000)^{* *}\end{array}$ & $\begin{array}{l}-0.001 \\
(0.022)\end{array}$ & $\begin{array}{l}0.001 \\
(0.000)^{* *}\end{array}$ & $\begin{array}{l}0.005 \\
(0.021)\end{array}$ & $\begin{array}{l}0.001 \\
(0.000)^{* *}\end{array}$ & $\begin{array}{l}0.005 \\
(0.021)\end{array}$ \\
\hline Constant & $\begin{array}{c}0.008 \\
(0.007)\end{array}$ & $\begin{array}{l}-0.369 \\
(0.471)\end{array}$ & $\begin{array}{c}0.005 \\
(0.007)\end{array}$ & $\begin{array}{l}-0.683 \\
(0.442)^{* *}\end{array}$ & $\begin{array}{l}-0.001 \\
(0.006)\end{array}$ & $\begin{array}{c}0.271 \\
(0.365)\end{array}$ & $\begin{array}{l}-0.001 \\
(0.006)\end{array}$ & $\begin{array}{c}0.320 \\
(0.362)\end{array}$ \\
\hline $\begin{array}{l}\text { Dummy Variable (=1, if loan } \\
\text { committed) }\end{array}$ & $\begin{array}{l}0.013 \\
(0.002)^{* * *}\end{array}$ & $\begin{array}{l}3.185 \\
(0.100)^{* * *}\end{array}$ & $\begin{array}{l}0.012 \\
(0.002)^{* * *}\end{array}$ & $\begin{array}{l}3.169 \\
(0.100)^{* * *}\end{array}$ & $\begin{array}{l}0.012 \\
(0.002)^{* * *}\end{array}$ & $\begin{array}{l}3.217 \\
(0.100)^{* * *}\end{array}$ & $\begin{array}{l}0.012 \\
(0.002)^{* * *}\end{array}$ & $\begin{array}{l}3.223 \\
(0.100)^{* * *}\end{array}$ \\
\hline Number of Observations & 379 & 379 & 379 & 379 & 379 & 379 & 379 & 379 \\
\hline Adjusted R-squared & 0.20 & 0.75 & 0.20 & 0.75 & 0.20 & 0.75 & 0.19 & 0.75 \\
\hline Sum Sq. Resids & 0.07 & 297.73 & 0.07 & 300.22 & 0.07 & 299.57 & 0.07 & 300.25 \\
\hline S.E. Equation & 0.01 & 0.90 & 0.01 & 0.90 & 0.01 & 0.90 & 0.01 & 0.90 \\
\hline
\end{tabular}

${ }^{1 /}$ Robust standard errors are in parentheses; *: significant at the 10 percent level; **: significant at the 5 percent level; and ***: significant at the 1 percent level. 
Table 2. Forecast Error Variance Decomposition of Loan Model ${ }^{1 /}$

\begin{tabular}{|c|c|c|c|c|c|c|c|c|c|}
\hline \multirow[t]{2}{*}{ Period } & \multirow[t]{2}{*}{ S.E. } & \multicolumn{2}{|c|}{ Institutions } & \multicolumn{2}{|c|}{ Donor Interest } & \multirow{2}{*}{$\begin{array}{c}\text { Own Factors } \\
\text { Loan }\end{array}$} & \multicolumn{3}{|c|}{ Other Factors } \\
\hline & & CPIA & $\begin{array}{l}\text { Government } \\
\text { Size }\end{array}$ & Exports & $\begin{array}{l}\text { Concession- } \\
\text { ality }\end{array}$ & & Program & ODA & Other \\
\hline 1 & 0.005 & 8.7 & 14.3 & 2.2 & 0.0 & 56.2 & 13.8 & 2.2 & 2.7 \\
\hline 2 & 0.037 & 8.1 & 13.2 & 2.0 & 5.5 & 52.6 & 13.8 & 2.3 & 2.5 \\
\hline 3 & 0.054 & 8.1 & 13.0 & 2.0 & 6.1 & 52.2 & 13.8 & 2.3 & 2.5 \\
\hline 4 & 0.068 & 8.0 & 13.0 & 2.0 & 6.2 & 52.1 & 13.8 & 2.3 & 2.5 \\
\hline 5 & 0.081 & 8.0 & 13.0 & 2.0 & 6.3 & 52.1 & 13.8 & 2.3 & 2.5 \\
\hline 6 & 0.093 & 8.0 & 13.0 & 2.0 & 6.3 & 52.1 & 13.8 & 2.3 & 2.5 \\
\hline 7 & 0.105 & 8.0 & 13.0 & 2.0 & 6.3 & 52.1 & 13.8 & 2.3 & 2.5 \\
\hline 8 & 0.117 & 8.0 & 13.0 & 2.0 & 6.3 & 52.1 & 13.8 & 2.3 & 2.5 \\
\hline 9 & 0.129 & 8.0 & 13.0 & 2.0 & 6.4 & 52.0 & 13.8 & 2.3 & 2.5 \\
\hline 10 & 0.141 & 8.0 & 13.0 & 2.0 & 6.4 & 52.0 & 13.8 & 2.3 & 2.5 \\
\hline
\end{tabular}

1/ Factorization; Structural.

Table 3. Forecast Error Variance Decomposition of Concessionality Model ${ }^{1 /}$

\begin{tabular}{|c|c|c|c|c|c|c|c|c|c|}
\hline \multirow[t]{2}{*}{ Period } & \multirow[t]{2}{*}{ S.E. } & \multicolumn{2}{|c|}{ Institutions } & \multicolumn{2}{|c|}{ Donor Interest } & \multirow{2}{*}{$\begin{array}{c}\text { Own Factors } \\
\begin{array}{c}\text { Concession- } \\
\text { ality }\end{array}\end{array}$} & \multicolumn{3}{|c|}{ Other Factors } \\
\hline & & CPIA & $\begin{array}{c}\text { Government } \\
\text { Size }\end{array}$ & Exports & Loan & & Program & ODA & Other \\
\hline 1 & 0.010 & 2.2 & 2.2 & 0.2 & 14.7 & 64.9 & 12.3 & 3.1 & 0.4 \\
\hline 2 & 0.014 & 2.6 & 2.2 & 0.2 & 64.5 & 14.9 & 12.3 & 3.1 & 0.1 \\
\hline 3 & 0.017 & 2.3 & 2.2 & 0.2 & 64.5 & 15.0 & 12.3 & 3.1 & 0.4 \\
\hline 4 & 0.020 & 2.3 & 2.2 & 0.2 & 64.5 & 15.0 & 12.3 & 3.1 & 0.4 \\
\hline 5 & 0.022 & 2.3 & 2.2 & 0.2 & 64.5 & 14.9 & 12.3 & 3.1 & 0.4 \\
\hline 6 & 0.024 & 2.3 & 2.2 & 0.2 & 64.5 & 14.9 & 12.3 & 3.1 & 0.4 \\
\hline 7 & 0.026 & 2.3 & 2.2 & 0.2 & 64.5 & 14.9 & 12.3 & 3.1 & 0.4 \\
\hline 8 & 0.028 & 2.3 & 2.2 & 0.2 & 64.5 & 14.9 & 12.3 & 3.1 & 0.4 \\
\hline 9 & 0.030 & 2.3 & 2.2 & 0.2 & 64.5 & 14.9 & 12.3 & 3.1 & 0.4 \\
\hline 10 & 0.032 & 2.3 & 2.2 & 0.2 & 64.5 & 14.9 & 12.3 & 3.1 & 0.4 \\
\hline
\end{tabular}

1/ Factorization; Structural. 


\section{Conclusion}

BRIC financing flows to LICs have been rising at a fast pace and are expected to become even more prominent. It is therefore important to understand the determinants of the countryallocation of the financing and degree of concessionality. We find that BRICs lend more to LICs with lower CPIA scores suggesting that they provide more financing to LICs with weaker institutions and governance. Land-locked, resource-scarce LICs receive significantly less financing. The degree of concessionality is negatively correlated with the amount of financing, suggesting that BRIC financing could be based on a commercial calculations - the higher the risks, the higher the returns. Consistent with this, countries with better institutional indicators also received greater concessionality.

We find that government size, institutional quality and whether a country has a Fund program are the most important explanatory variables that explain the variation in BRIC financing. The amount of loan commitments and whether a country has a Fund program are the main variables driving variation in the degree of concessionality. However, these variables are only able to explain about one third of the variation in the BRIC financing and degree of concessionality suggesting that other factors may be important in driving the across country variation.

There are important caveats. The models may not be fully taking into account heterogeneity across the BRICs and in the drivers of their financing and concessionality to the individual LICs. Also, structural changes in development assistance policy could imply significantly different relationships going forward. Future work could also explore the impact of political factors in driving BRIC financing. 


\section{Appendix}

Data on BRIC financing used in this analysis are largely based on the World Bank's debt database. The World Bank debt database has information on loan commitments based on recipient country data and includes 49 countries spanning 2000-2008 (see Table A1 for country list).

The BRIC data are not directly comparable with ODA mainly because the modalities of BRIC financing generally differs from the concepts used in the DAC methodology. For example, China's data excludes items such as humanitarian aid that it does not consider as development assistance, while the OECD includes this aid (Davies et al., 2008). Thus, the estimates of China's grants could be underestimated.

Table A.1 Country List

\begin{tabular}{llll}
\hline Angola & Dominica & Madagascar & Sierraleone \\
Bangladesh & Eritrea & Malawi & Sudan \\
Benin & Ethiopia & Maldives & Tajikistan \\
Bhutan & Gambia,the & Mali & Tanzania \\
Boliva & Georgia & Mauritania & Togo \\
Burkina Faso & Ghana & Mozambique & Tonga \\
Burundi & Grenada & Nepal & Uganda \\
Cambodia & Guinea & Nicaragua & Yemen \\
Cameroon & Guyana & Niger & Zambia \\
Capeverde & Honduras & Nigeria & Zimbabwe \\
Chad & Kenya & Samoa & \\
Congo,dem.Rep. & Kyrgyz & Sao Tome \& Principe \\
Coted'ivoire,republic of & Lesotho & Senegal & \\
\hline
\end{tabular}

Source: World Bank debt database 
Table A.2 List of Variables in Dynamic Panel Analysis ${ }^{1 /}$

\begin{tabular}{ll}
\hline Variable & Rationale \\
\hline BRIC financing & $\begin{array}{l}\text { Dependent variable and debt impact in the degree of } \\
\text { concessionality model } \\
\text { ODA flows }\end{array}$ \\
Same as above \\
Degree of concessionality & Variable capturing impact of concessionality. \\
Income & Relative income is used as a proxy for "needs" \\
Infant mortality & Proxy for "physical needs" \\
Reserves & Proxy for "foreign exchange needs" \\
Trade openness & Proxy for donor interests \\
Imports & Proxy for donor commercial interests \\
Exports & Proxy for donor commercial interests \\
Resource-rich & Proxy for donor commercial interests \\
Resource-scarce landlocked & Proxy for donor commercial interests \\
Resource-scarce coastal & Proxy for donor commercial interests \\
Regional dummy & Proxy for 'political interest" (geography) \\
Fund program & Reflects impact of Fund conditionality \\
Size of government & Proxy for institutions, focusing on size and scope of \\
CPIA & government. \\
Government effectiveness & Proxy for institutions, focuses on quality of institutions, \\
Planning & Proxy for institutions, focusing on governance \\
Transparency & Proxy for institutions, focusing on budget planning \\
\hline
\end{tabular}

Table A.3 Variable Definitions in the Dynamic Panel Model ${ }^{1 /}$

\begin{tabular}{|c|c|c|}
\hline Variable & Description & Source \\
\hline BRIC financing & $\begin{array}{l}\text { The individual BRIC country financing commitments (on a loan-by-loan basis) are } \\
\text { aggregated to create total BRIC financing. The loan amount is then divided by GDP }\end{array}$ & World Bank debt database \\
\hline ODA flows & Total commitments by all donors reporting to the OECD, as a share of GDP & OECD; WEO, IMF \\
\hline Degree of concessionality & $\begin{array}{l}\text { The grant equivalent of a loan is defined as the difference between the present values } \\
\text { of the loan's disbursements and stream of expected debt service payments }\end{array}$ & $\begin{array}{l}\text { World Bank debt database; } \\
\text { IMF grant element calculator }\end{array}$ \\
\hline Imports & Imports (from BRICs) as a share of GDP, lagged by one period & WEO, IMF \\
\hline Exports & Exports (from BRICs) as a share of GDP, lagged by one period & WEO, IMF \\
\hline Resource-rich dummy & Equal to 1 if mineral-resource rich (at present or prospective); 0 otherwise & $\begin{array}{l}\text { WEO, IMF and various other } \\
\text { sources }\end{array}$ \\
\hline Resource-scarce landlocked dummy & Equal to 1 if mineral-resource scarce and landlocked; 0 otherwise & $\begin{array}{l}\text { WEO, IMF and various other } \\
\text { sources }\end{array}$ \\
\hline Resource-scarce port dummy & Equal to 1 if mineral-resource scarce and coastal with a port; 0 otherwise & $\begin{array}{l}\text { WEO, IMF and various other } \\
\text { sources }\end{array}$ \\
\hline Regional dummy & A dummy reflecting a country's regional location & IMF \\
\hline Size of government & Public consumption as a share of GDP, lagged by one period & WEO, IMF \\
\hline IMF Dummy & A dummy reflecting IMF program engagement & IMF \\
\hline $\begin{array}{l}\text { Quality of institutions, policies \& } \\
\text { management }\end{array}$ & CPIA indicators & World Bank \\
\hline Government effectiveness & Governance indicators & $\begin{array}{l}\text { World Bank, Kaufman and } \\
\text { Kraay governance indicators }\end{array}$ \\
\hline Planning & Planning index & Dabla-Norris et al, 2010 \\
\hline Transparency & Transparency index & Dabla-Norris et al, 2010 \\
\hline
\end{tabular}

Notes: WEO "World Economic Outlook database; MONA : Monitoring of Fund Arrangements database; WDI: World Development Indicators 
Table A.4 Panel Unit Root Test ${ }^{1 /}$

\begin{tabular}{|c|c|c|c|c|}
\hline \multirow{3}{*}{ Variable } & \multicolumn{4}{|c|}{ Levin, Lin \& Chy t* } \\
\hline & \multicolumn{2}{|c|}{ Levels } & \multicolumn{2}{|c|}{ First Differences } \\
\hline & t-rho & & t-rho & \\
\hline Loan & -8.19 & 0.00 & -31.34 & 0.00 \\
\hline ODA & -30.53 & 0.00 & -50.81 & 0.00 \\
\hline Concessionality & -17.31 & 0.00 & -23.02 & 0.00 \\
\hline GDP & -25.59 & 0.00 & -52.65 & 0.00 \\
\hline Imports & -27.16 & 0.00 & -38.87 & 0.00 \\
\hline Exports & -10.07 & 0.00 & -15.72 & 0.00 \\
\hline Government consumption & -8.08 & 0.00 & -13.68 & 0.00 \\
\hline CPIA & -17.99 & 0.00 & -41.66 & 0.00 \\
\hline Government effectiveness & -16.47 & 0.00 & -36.55 & 0.00 \\
\hline
\end{tabular}

Table A.5 Model Stability Test

Inverse Roots of AR Characteristic Polynomial

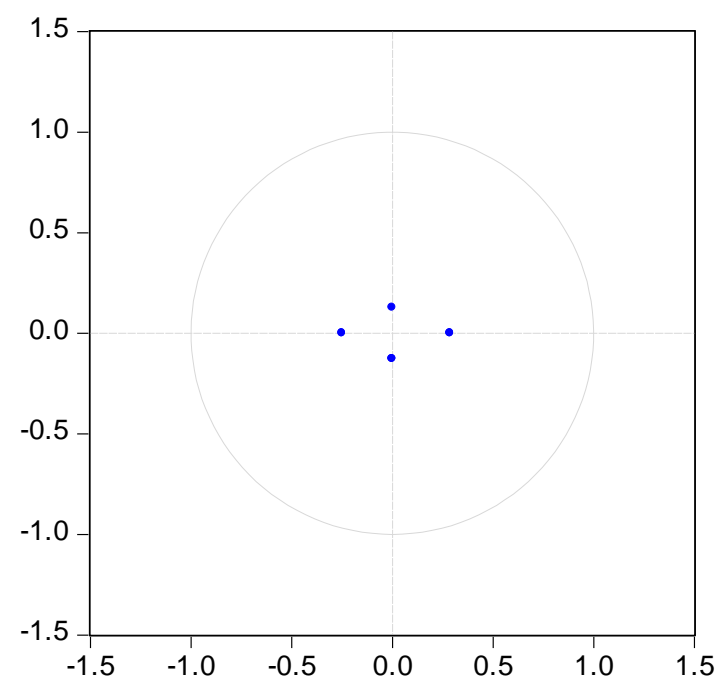


Table A.6 Robustness: Panel VAR and OLS ${ }^{1 /}$

\begin{tabular}{|c|c|c|c|c|}
\hline & \multicolumn{2}{|c|}{ Panel VAR } & \multirow{2}{*}{$\frac{\text { Panel OLS }}{\text { Loan }}$} & \multirow{2}{*}{$\begin{array}{r}\text { Panel OLS } \\
\text { Conces- } \\
\text { sionality }\end{array}$} \\
\hline & Loan & $\begin{array}{l}\text { Conces- } \\
\text { sionality }\end{array}$ & & \\
\hline \multirow[t]{2}{*}{ Loan (1 lag) } & 0.089 & -10.150 & 0.088 & -12.480 \\
\hline & $(0.052) * *$ & $(3.354)^{* * *}$ & $(0.052) * *$ & $(3.594)^{* * *}$ \\
\hline \multirow[t]{2}{*}{ Concessionality (1 lag) } & 0.000 & 0.076 & 0.000 & 0.085 \\
\hline & $(0.000)$ & $(0.027)^{* * *}$ & $(0.000)$ & $(0.031)^{* * *}$ \\
\hline \multirow[t]{2}{*}{ GDP p.c ratio } & 0.002 & -0.072 & 0.002 & -0.022 \\
\hline & $(0.001)^{* *}$ & $(0.058)$ & $(0.001)^{* *}$ & $(0.066)$ \\
\hline \multirow[t]{2}{*}{ ODA } & 0.002 & 0.501 & 0.002 & 0.770 \\
\hline & $(0.000)$ & $(0.019)^{* *}$ & $(0.005)$ & $(0.353)^{* * *}$ \\
\hline \multirow[t]{2}{*}{ IMF program (incl. PSI) } & -0.001 & 0.225 & -0.002 & 0.273 \\
\hline & $(0.002)$ & $(0.108)^{* * *}$ & $(0.002)$ & $(0.122)^{* * *}$ \\
\hline \multirow[t]{2}{*}{ Asia } & 0.009 & 0.002 & 0.009 & -0.174 \\
\hline & $(0.003)^{* * *}$ & $(0.180)$ & $(0.003)^{* * *}$ & $(0.203)$ \\
\hline \multirow[t]{2}{*}{ Population } & 0.000 & -0.034 & 0.000 & -0.025 \\
\hline & $(0.000)$ & $(0.019) * *$ & $(0.000)$ & $(0.022)$ \\
\hline \multirow[t]{2}{*}{ Resource-scarce Port } & -0.001 & 0.091 & -0.001 & 0.207 \\
\hline & $(0.003)$ & $(0.197)$ & $(0.003)$ & $(0.223)$ \\
\hline \multirow[t]{2}{*}{ Resource-scarce Landlocked } & -0.005 & 0.079 & -0.005 & -0.152 \\
\hline & $(0.003)^{*}$ & $(0.208)$ & $(0.003)^{*}$ & $(0.234)$ \\
\hline \multirow[t]{2}{*}{ Size of government (1 lag) } & 0.016 & -1.279 & 0.013 & -1.998 \\
\hline & $(0.009)^{*}$ & $(0.580)^{* * *}$ & $(0.009)^{*}$ & $(0.658)^{* * *}$ \\
\hline \multirow[t]{2}{*}{ CPIA } & -0.003 & 0.277 & -0.003 & 0.261 \\
\hline & $(0.002)^{* *}$ & $(0.096)^{* * *}$ & $(0.002) * *$ & $(0.110)^{* * *}$ \\
\hline \multirow[t]{2}{*}{ Exports to BRICs ( 1 lag) } & -0.021 & -2.339 & -0.021 & -2.435 \\
\hline & $(0.020)$ & $(1.280)^{* *}$ & $(0.020)$ & $(1.424)^{*}$ \\
\hline \multirow[t]{2}{*}{ Trend } & 0.001 & 0.007 & 0.001 & 0.011 \\
\hline & $(0.000)^{* *}$ & $(0.021)$ & $(0.000)^{* *}$ & $(0.024)$ \\
\hline \multirow[t]{2}{*}{ constant } & 0.008 & -0.369 & 0.008 & -0.434 \\
\hline & $(0.007)$ & $(0.471)$ & $(0.007)$ & $(0.536)$ \\
\hline \multirow{3}{*}{$\begin{array}{l}\text { Dummy variable (=1, if loan } \\
\text { committed) }\end{array}$} & & & & \\
\hline & 0.013 & 3.185 & 0.013 & 3.073 \\
\hline & $(0.002)^{* * *}$ & $(0.100)^{* * *}$ & $(0.002)^{* * *}$ & $(0.113)^{* * *}$ \\
\hline Number of observations & 379 & 379 & 384 & 384 \\
\hline Adjusted R-squared & 0.20 & 0.75 & 0.20 & 0.69 \\
\hline Sum sq. resids & 0.07 & 297.73 & 0.07 & 389.46 \\
\hline S.E. equation & 0.01 & 0.90 & 0.01 & 1.02 \\
\hline
\end{tabular}




\section{References}

Ali, A., and H. Isse, 2006, “An Empirical Analysis of the Determinants of Foreign Aid: A Panel Approach,” International Advances in Economic Research, Vol. 12, pp. 241-250.

Bierens, H., 2004, “VAR Models with Exogenous Variables,” mimeo.

Brautigam, D., 2010, The Dragon's Gift: The Real Story of China in Africa (New York: Oxford University Press Inc.).

Burnside, C., and D. Dollar, 2000, “Aid, Policies, and Growth,” American Economic Review, Vol. 90(4), pp. 847-868. , 2004, “Aid, Policies, and Growth: Revisiting the Evidence,” World Bank Policy Research Working Paper 3251 (Washington: World Bank).

Claessens, S., D. Cassimon, and B. Van Campenhaut, 2007, "Empirical Evidence on the New International Architecture,” IMF Working Paper 07/277 (Washington: International Monetary Fund).

Collier, P., and S. O’Connell, 2007, “Opportunities and Choices” The Political Economy of Economic Growth in Africa, 1960-2000, ed. by Ndulu, O’Connell, Bates, Collier, Soludo, Azam, Fosus, Gunning, and Njinkeu (Cambridge: Cambridge University Press).

Cordella, T., and H. Ulku, 2004, “Grants Versus Loans,” IMF Working Paper 04/161 (Washington: International Monetary Fund).

Dabla-Norris, E., R. Allen, L. Zanna, T. Prakash, E. Kvintradze, V. Lledo, I. Yackovlev, and S. Gollwitzer, 2010, "Budget Institutions and Fiscal Performance in Low-Income Countries,” IMF Working Paper 10/80 (Washington: International Monetary Fund).

Davies, M, H. Edinger, N. Tay, and S. Naidu, 2008, “How China Delivers Development Assistance to Africa,” University of Stellenbosch (South Africa: Centre for Chinese Studies).

Easterly, W., 1999, “Life during Growth,”Journal of Economic Growth, Vol. 4, pp. 239-276.

Gounder, R., 1994, “Empirical Results of Aid Motivations: Australia’s Bilateral Aid Program,” World Development, Vol. 22(1), pp. 99-113.

Hopkins, R., 2000, “Political Economy” in Tarp, F. “Foreign Aid and Development: Lessons Learnt and Directions for the Future,” (Routledge: London and New York).

Kaufmann, D., A. Kraay, and M. Mastruzzi, 2009, Governance Matters VIII. Governance Indicators for 1996-2008, World Bank Policy Research Paper No. 4978 (Washington: World Bank).

Koeda, J., 2004, “Grants or Concessional Loans? Aid to Low-Income Countries with a Participation Constraint,” University of California, Los Angeles, mimeo.

Kosack, S., 2003, "Effective Aid: How Democracy Allows Development Aid to Improve the Quality of Life,” World Development, Vol. 31(1), pp. 1-22. 
Maizels, A., and M. Nissanke, 1984, “Motivations for Aid to Developing Countries,” World Development, pp. 879-900.

Manning, R., 2006, “Will Emerging Donors Change the Face of International Co-Operation?” Development Policy Review, Vol. 2494, pp. 371-385.

McKinlay, R. D., and R. Little, 1979, “The U.S. Aid Relationship: A Test of the Recipient Need and the Donor Interest Models," Political Studies, Vol. 27(2), pp. 236-250.

McGillivray, M., and E. Oczkowski, 1992, "A Two-Part Sample Selection Model of British Bilateral Foreign Aid Allocation,” Applied Economics, Vol. 24, pp. 1311-19.

Mwase, N., and Y. Yang, 2011, "Philosophies of BRIC Development Flows and Implications for LICs,” forthcoming, IMF Working Paper (Washington: International Monetary Fund).

Neumayer, E., 2003, The Pattern of Giving Aid: The Impact of Good Governance on Development Assistance, Routledge Studies in Development Economics 34 (Routledge: London and New York).

Odedokun, M., 2004, "Multilateral and Bilateral Loans versus Grants: Issues and Evidence,” The World Economy, Vol. 27, pp. 239-63.

OECD, 2010, "Beyond the DAC: The Welcome Role of Other Providers of Development Cooperation," OECD Development Cooperation Directorate, DCD Issues Brief (Smith, K., Yamashiro, T., and Zimmerman, F., May (Paris: OECD).

OECD (a), Development Co-operation Report, Various Issues (Paris: OECD).

Radelet, S., 2006, “Foreign Aid,” in Amitava Dutt and Jamie Ros (eds.) International Handbook of Development Economics (London: Edward Elgar).

Round, J., and M. Odedokun, 2004, “Aid Effort and its Determinants," International Review of Economics and Finance, pp. 293-309.

Stock, J., and M. Yogo, 2002, “Testing for Weak Instruments in Linear IV Regression,” NBER Working Paper No. 0284 (Cambridge, Massachusetts).

White, H., and M. McGillivray, 1995, "How Well is Aid Allocated? Descriptive Measures of Aid Allocation: A Survey of Methodology and Results," Development and Change, Vol. 26 (1), pp. 63-83. 